\title{
Vitamin A status of neonatal foals assessed by serum retinol concentration and a relative dose response test
}

\author{
K.M. Greiwe-Crandell, D.S. Kronfeld, L.S. Gay, D. Sklan and P.A. Harris \\ Va. Tech M.A.R.E. Center, Middleburg, USA
}

Summary

The objective of the study was to evaluate the vitamin A status of the newborn foal. Serum retinol and the relative dose response (RDR) test between 12 and 24 hours postpartum were used to assess vitamin A status in 28 Thoroughbred foals born to mares in 3 different feed groups being supplemented with vitamin A palmitate, B-carotene or a placebo. A correlation was found between foal and mare serum. Serum retinol levels were lower and RDRs were higher in the newborns than in the mares. No differences were found between foals born of mares with different vitamin A supplementation.

keywords: $\quad$ vitamin $\mathrm{A}$, equine neonate, serum retinol, RDR

\begin{abstract}
Der Vitamin-A-Status neugeborener Fohlen, überprüft durch Bestimmung der Serum-Retinol-Konzentrationen und einen DosisResponse-Test

In der vorliegenden Untersuchung sollte der Vitamin A Status neugeborener Fohlen überprüft werden. Dazu wurden der Serum-Retinol-Spiegel und der relative Dosis-Response-Test 12 und 24 Stunden post partum bei 28 Vollblutfohlen, deren Mütter in drei unterschiedlichen Fütterungsgruppen mit Vitamin A Palmitat, B-Carotin oder einem Placebo supplementiert wurden, verwendet. Die Serumwerte von Fohlen und Mutter korrelierten miteinander. Die Serum-Retinol-Spiegel waren bei den Fohlen niedriger, die Reaktion auf die Retinolgabe stärker als bei den Stuten. Zwischen Fohlen, deren Mütter unterschiedliche Vitamin A Gaben erhaiten hatten, bestand kein Unterschied.
\end{abstract}

Schlüsselwörter: Vitamin A, neugeborenes Fohlen, Serum-Retinol, relativer Dosis-Response-Test

\section{Introduction}

Serum retinol concentration is not usually regarded as a sensitive indicator of vitamin A status. The blood concentration of retinol is regulated mainly by the rate of its secretion from the liver in the form of retinol bound to retinol binding protein. Hepatic stores are usually capable of maintaining a constant level of serum retinol despite variations in dietary supply (Blomhoff et al. 1991). The relative dose response (RDR) test, based on the response of serum retinol to an oral dose of retinol palmitate, was developed in rats as a more sensitive test of vitamin A depletion (Loerch et al. 1979). An RDR test has been used to demonstrate depleted vitamin A status in mature horses kept in stalls (Jarrett and Schurg 1987). Seasonal depletion of vitamin A has been demonstrated using the RDR test in grazing horses (Greiwe-Crandell et al. 1995a,b).

Evaluation of the vitamin A status in the newborn foal using the RDR test has not been investigated to our knowledge. Newborn and older foal vitamin A serum values have been found to be lower than values of their dams (Stowe 1982; Mäenpää et al. 1988), and liver concentration of vitamin $A$ in neonatal foals was similar to that found previously in deficient adult horses (Irwin et al. 1991). The objective of this study was to compare vitamin A status in mares and newborn foals using the RDR test.

\section{Materials and methods}

\section{Horses}

Forty-five Thoroughbred mares were divided into 3 groups and kept on different forage systems for 30 months. The first forage system was a dry lot where mares were fed 2 year old grass hay and a concentrate made from ingredients low in B-carotene and without added vitamin $\mathrm{A}(\mathrm{HC})$. The second and third systems were bluegrass/clover pastures supplemented with alfalfa/grass hay during the winter $(\mathrm{PH})$ where one of the groups was also fed the vitamin $\mathrm{A}$ free concentrate $(\mathrm{PHC})$. After 9 months of vitamin $\mathrm{A}$ depletion, each group of 15 mares was divided into 3 subgroups: 5 mares were supplemented with vitamin A palmitate at twice the NRC requirement (NRC 1989) (A); 5 mares were given $B$-carotene at the equivalent of twice the NRC requirement of vitamin $A(B)$; and 5 mares were given a placebo (C). Supplements were given 2 times per week orally and individually. Every 2 months vitamin $A$ status was assessed by RDR test as well as serum retinol concentration. During March - July (1991) all of the mares were exposed to a stallion (pasture bred), and of the 45 mares 39 were found pregnant (by ultrasound) at 30 days, 34 foaled (1992) to produce 30 live foals.

\section{Sampling}

Twenty eight of these foals were used for the study. Jugular blood samples were taken between 12 and 24 hours postpartum after the foal was walking and suckling. Samples were collected into 10 $\mathrm{mL}$ tubes (Vacutainer, Becton Dickinson, Rutheford NJ) and placed immediately in a light excluding container. They were centrifuged within $30 \mathrm{~min}$., and the serum stored at $-20^{\circ} \mathrm{C}$ until thawed for assay.

All samples were prepared in duplicate. Protein in serum was precipitated with ethanol and retinol was extracted with hexane after addition of retinol acetate as an internal standard (Bieri et al. 


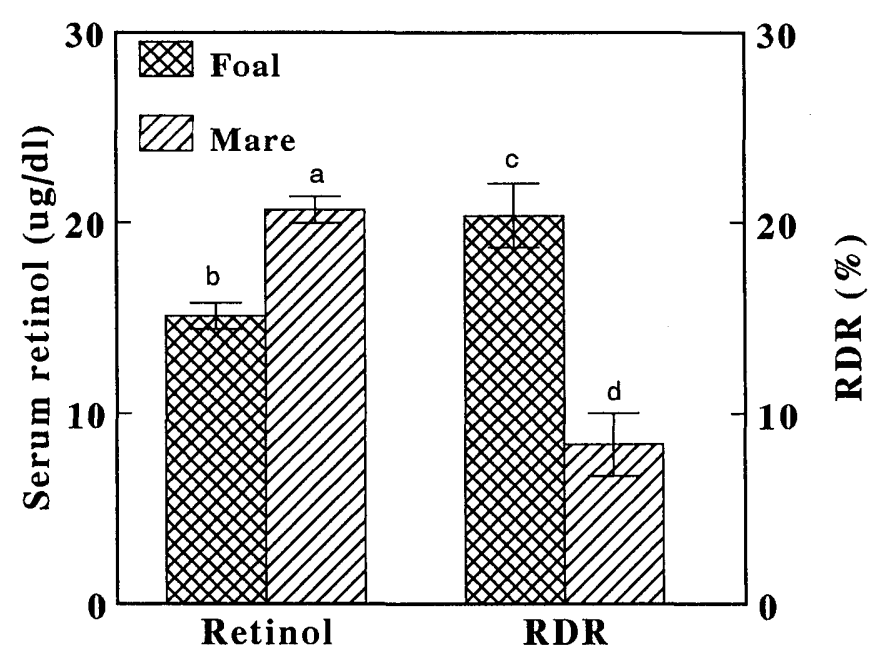

Fig. 1: Mean serum retinol and relative dose response (RDR) for newborn foals and mares. ${ }^{a b P}=0.0001$ and $\mathrm{cd} P=0.0001$

Mittlere Serum-Retinol-Werte und RDR-Werte bei neugeborenen Fohlen und Stuten. ${ }^{a b P}=0.0001$ and ${ }^{\mathrm{dd} P}=0.0001$

1979, Miller and Yang 1985), then samples were injected into a HPLC (Waters Bondepak Reverse Phase C18 Column [3.9×300 $\mathrm{mm}]$ with Waters 484 Tunable Absorbance Detector set at 325 $\mathrm{nm}$ and Waters 600E Controller, Millipore, Milford, MA). Solvent was $98 \%$ methanol and $2 \%$ water, with a flow rate of $1 \mathrm{~mL} / \mathrm{min}$ for 7 min with retention time for retinol and retinyl acetate eluding at 4-5 and 5-6 min respectively.

The RDR test consisted of taking a blood sample and dosing orally with $50,000 \mathrm{IU}$ vitamin A paimitate in corn oil, then taking the second sample 5 hours later. The RDR was calculated by the following equation:

$$
\mathrm{RDR}=100\left(T_{5}-\mathrm{T}_{0}\right) / \mathrm{T}_{5} \%
$$

where $T_{0}$ and $T_{5}$ are the first and second serum retinol concentrations, respectively. The higher the percent RDR, the more depleted the animal (Loerch et al. 1979).

\section{Statistics}

The RDR and serum retinol data were summarized as least-squares means and standard errors and examined by ANOVA using the GLM procedures of SAS (SAS/STAT Version 6, SAS Institute, Cary, $\mathrm{NC})$. Linear regressions of foal data on corresponding mare data were analyzed (SlideWrite Plus, Version 3.00, Advanced Graphics Software, Carlsbad, CA).

\section{Results and discussion}

Vitamin A status as assessed by serum retinot and the RDR was lower in the foals than in the mares (Fig. 1). Mean foal serum levels were $26 \%$ lower than in the mare $(P=0.0001)$. Mean foal RDR percentages were $59 \%$ higher than in the mares $(P=0.0001)$ As the homeostatic mechanism of vitamin A metabolism maintains a constant level in the blood, one cannot ascertain whether the lower serum levels alone in the foal are a physiologic norm or a depleted level. The fact that the RDRs (which are an indirect measurement of hepatic stores) are higher in the foals suggests that the lower serum retinol levels are in fact a reflection of a relative depletion in the foals at birth. Irwin et al. (1991) analysed liver samples of newborn foals before suckling and found the hepatic vitamin A levels much lower than the levels of mature horses. This low liver vitamin A content is consistent with the high RDR in newborn foals (Fig. 1), both indicating low hepatic reserves.

The results of this study suggest that the vitamin A status of newborn foals was low. Similar results have been found with serum vitamin A activity in newborn foals (Stowe 1982) and with RDR tests in newborn lambs (Kronfeld et al. 1990). Vitamin A status improved rapidly with consumption of colostrum in both foals and lambs. Mares were found to increase the amount of vitamin $A$ in their colostrum at least 2-fold during the first 24 hours after birth (Stowe, 1982). Improvement of immune competence by colostrum consumption involves the transfer of immuoglobulins and, in the light of these studies, perhaps also the transfer of vitamin A. Public health studies have revealed the powerful influence of vitamin A status on susceptibility to infectious disease (West et al. 1989).

The effect of diet of the dam on the newborn was not very clear. The $\mathrm{PH}$ group of newborns appeared to be influenced the most by vitamin A status of the mare. The mean serum retinol for the $\mathrm{PH}$ group was higher than in the $\mathrm{HC}(\mathrm{P}=0.034)$ and the $\mathrm{PHC}(\mathrm{P}=$ 0.086) groups of foals (Fig. 2, upper). While the mean foal RDR for the $\mathrm{HC}$ group was higher than $\mathrm{PHC}$ or $\mathrm{PH}$ groups, it was not significant (Fig. 2, lower). Dietary effect on vitamin A status is more clearly seen in the mares. Serum retinol in the mares was higher in the $\mathrm{PHC}(\mathrm{P}=0.006)$ and $\mathrm{PH}(\mathrm{P}=0.006)$ groups than the $\mathrm{HC}$ group (Fig. 2, upper). The same pattern was also seen with the RDR test, the $\mathrm{HC}$ group of mares was higher than $\mathrm{PH}(\mathrm{P}=0.033)$ and $\mathrm{PHC}(\mathrm{P}=0.1)$ groups (Fig. 2, lower). Both $\mathrm{PHC}$ and $\mathrm{PH}$ groups had access to abundant carotene in the green grass of the pasture during this time of year which may account for the replete vitamin A status.

Supplementation with either vitamin A palmitate or B-carotene in the dam had a moderate influence on newborn foal serum levels (Fig. 3, upper) or RDR tests (Fig. 3, lower). Although mean serum retinol concentration was slightly higher in the $\mathrm{B}$ group of mares than in the $A$ group, the RDR test revealed that the $B$ group was more depleted than the $A$ group $(P=0.099)$. Supplementation of this form of water soluble B-carotene was found to be an ineffective source of vitamin $A$ in the mares as reported in Greiwe-Crandell et al. (1995b).

Correlations were found between foal and mare serum retinol levels ( $r a l=0.363, P=0.058$ ) and RDRs ( $r$ al $=0.379, P=0.047$ ). The linear regression estimated foal values from the mares with the following prediction equations for serum retinol and for RDR:

$$
\mathrm{Sr}_{\mathrm{f}}=9.21+0.29 \mathrm{Sr}_{\mathrm{m}}
$$

where $\mathrm{Sr}_{\mathrm{f}}=$ serum retinol of foal $(\mathrm{g} / \mathrm{dl}), \mathrm{Sr}_{\mathrm{m}}=$ serum retinol of $\mathrm{ma}$ re $(g / d)$, and

$$
\mathrm{RDR}_{\mathrm{f}}=18.25+0.47 \mathrm{RDR}_{\mathrm{m}}
$$

where $R D R_{f}=$ relative dose response of foal $(\%)$, and $R D R_{m}=$ relative dose response of mare (\%).

In conclusion, the RDR test has elucidated the trend seen previously in the serum retinol levels and has demonstrated a low vitamin A status in the newborn foal. 

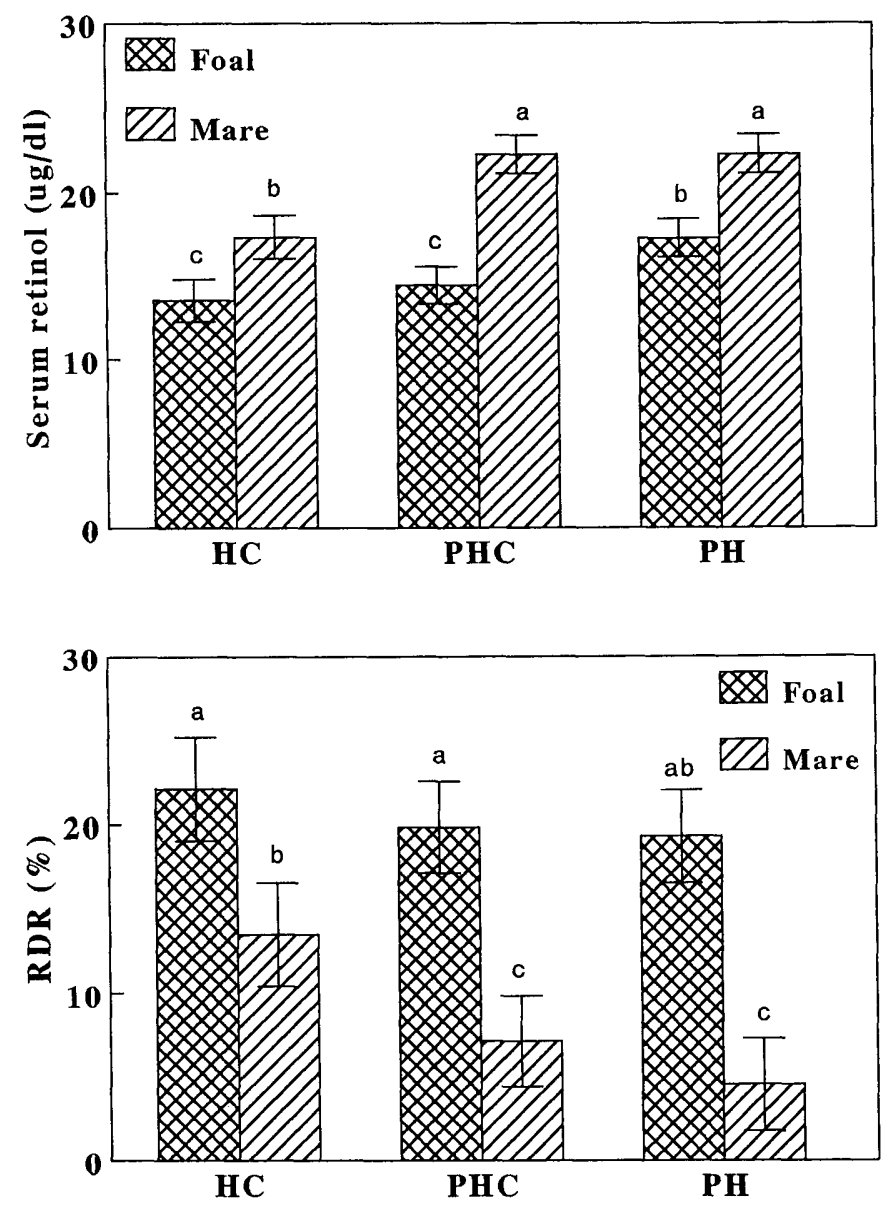

Fig. 2: Mean serum retinol (upper) and relative dose response (RDR) (lower) in newborn foals and mares for the 3 diet groups: hay \& concentrate $(\mathrm{HC})$, pasture, hay \& concentrate $(\mathrm{PHC})$, pasture \& hay $(\mathrm{PH})$. Upper: ${ }^{\mathrm{ab} P} \neq 0.0057,{ }^{a c P}<0.0001,{ }^{b c P}<0.0856$. Lower: ${ }^{a b P} \neq 0.12$, ac $P \neq 0.0028$, bc $P \neq 0.1$.

Mittlere Serum-Retinol-Werte (oben) und RDR-Werte (unten) bei neugeborenen Fohlen und Stuten der drei Fütterungsgruppen: Heu \& Konzentrat $(\mathrm{HC})$, Weide, Heu \& Konzentrat $(\mathrm{PHC})$, Weide und Heu (PH). Oben: ${ }^{a b} P \neq 0.0057$, ${ }^{a c} P<0.0001,{ }^{b c P}<0.0856$; Unten: ${ }^{a b P} \neq 0.12,{ }^{a c P} \neq 0.0028,{ }^{b c} P \neq 0.1$

\section{References}

Bieri, J. G., Tolliver, G. L. and Catignani, G. L. (1979): Simultaneous determination of alpha-tocopherol and retinoi in plasma or red blood cells by high pressure liquid chromatography. Amer. J. Clin. Nutr. 32, 2143-2149.

Blomhoff, R., Green, M. H., Green, J. B., Berg, T. and Norum, K. R. (1991): Vitamin A metabolism: new perspectives on absorption, transport and storage. Physiol. Rev. 71, 951-990.

Greiwe-Crandell, K. M., Kronfeld, D. S., Gay, L. A. and Sklan, D. (1995a): Seasonal vitamin A depletion in grazing horses is assessed better by the relative dose response test than by serum retinol concentration. J. Nutr. 125, 2711-2716.

Greiwe-Crandell, K. M., Kronfeld, D. S. and Sklan, D. (1995b): Vitamin A and beta-carotene supplementation in horses on different forage systems. Annales de Zootechie 44(Suppl 1), 308.

Inwin, L. N., Robberson, J. A. and Crouch, G. (1991): Hepatic vitamin A and carotene levels in the newborn foal. Equine Vet. Sci. 11, 278-280

Jarrett, S. H. and Schurg, W. (1987): Use of a modified relative dose response test for determination of vitamin A status in horses. Nutr. Rep. Internat. $35,733-742$.

Kronfeld, D. S., Sklan, D. and Donoghue, S. (1990): Vitamin A relative dose response tests to assess retinol status in neonates. Proc. 2nd internat. Conf. Vet. Perinatal. p. 63
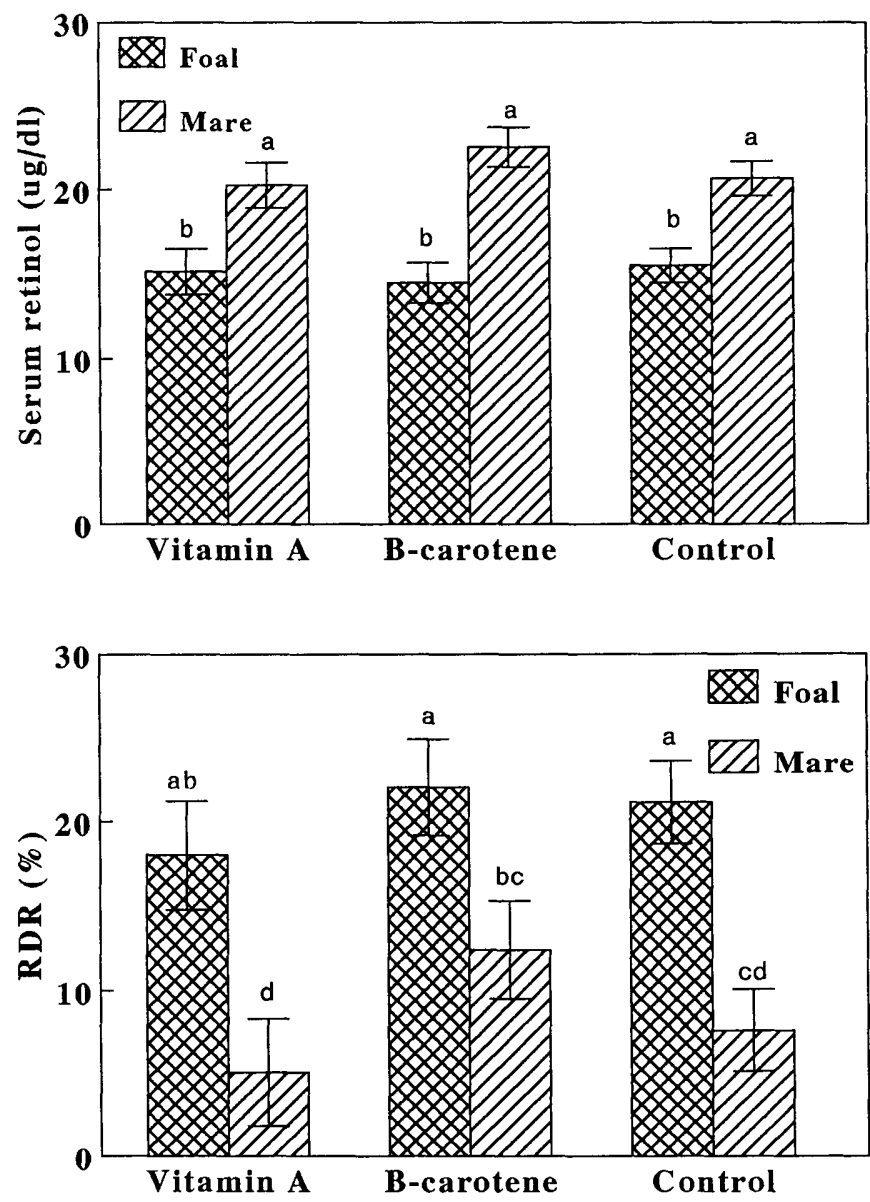

Fig. 3: Mean serum retinol (upper) and relative dose response (RDR) (lower) in newborn foals and mares for the 3 supplement groups: vitamin $A, B$-carotene, control (placebo). Upper: abP $\neq 0.0009$. Lower: $a b P \neq 0.025, a c P \neq 0.0003, a d P \neq 0.0003, b c P \neq 0.0143$, $\operatorname{bc} P \neq 0.0071, \operatorname{cd} P \neq 0.0986$

Mittlere Serum-Retinol-Werte (oben) und RDR-Werte (unten) bei neugeborenen Fohlen und Stuten der drei Fütterungsgruppen: Vitamin A, B-Carotin, Kontrolle (Placebo). Oben: abP $\neq 0.0009$; Unten: abP $\neq 0.025, a c P \neq 0.0003, a d P \neq 0.0003,{ }^{b c P} \neq 0.0143$, bdP $\neq 0.0071$, cdP $\neq 0.0986$

Loerch, J. D., Underwood, B. A. and Lewis, K. C. (1979): Response of plasma levels of vitamin $A$ as an indicator of hepatic vitamin $A$ reserves in rats. J. Nutr. 109, 78-86.

Mäenpää, P. H., Pirhonen, A. and Koskiene, E. (1988): Serum profiles of vitamins $A, E$, and $D$ in mares and foals during different seasons. J. Anim. Sci. 66, 1418-1423.

Miller, K. W. and Yang, C.S. (1985): An isocratic high-performance liquid chromatography method for the simultaneous analysis of plasma retinol, alpha-tocopherol, and various carotenoids. Anal. Bioch. 145, 21-26.

National Research Council (1989): Nutrient Requirements of Horses, 5th revised edition. National Academy Press, Washington, D.C.

Stowe, H. D. (1982): Vitamin A profiles of equine serum and milk. J. Anim. Sci. $54,76-81$

West, Jr., K. P., Howard, G. R. and Sommer, A. (1989): Vitamin A and infection: public health implication. Annu. Rev. Nutr. 9, 63-86.

This study was supported in part by Mr. Paul Mellon, Upperville, Virginia and the Waltham Centre for Pet Nutrition.

Kathleen M. Greiwe-Crandell

Va. Tech M.A.R.E. Center

5527 Sullivans Mill Road

Middleburg, VA 22117 USA 